\title{
VARIATION IN STAGE STRUCTURE AND FITNESS TRAITS BETWEEN ROAD VERGE AND MEADOW POPULATIONS OF COLCHICUM AUTUMNALE (LILIACEAE): EFFECTS OF HABITAT QUALITY
}

\author{
LUCYNA MRÓZ \\ Department of Ecology and Nature Protection, Wrocław University \\ Kanonia 6/8, 50-328 Wrocław, Poland \\ e-mail: mrozl@biol.uni.wroc.pl
}

(Received: April 18, 2005. Accepted: August 10, 2005)

\begin{abstract}
The frequency distribution and density of three life stages as well as fitness components of the perennial plant Colchicum autumnale growing in the unmanaged road verges and in the extensive mown and grazed meadows in the Sudeten Mts. were studied. Furthermore, investigated were the effects of population size and plant size (measured as number of flowers) on reproductive success and explored if variation in reproductive and vegetative traits of adults could be associated with soil characteristics. The t-test indicated that proportions of subadults and reproductive adults were significantly lower in verge than in meadow populations, and of vegetative adults significantly higher. The plant density of reproductive adults and the reproductive adults to all adults ratio were significantly lower in verge populations compared to meadow populations. Although habitat type accounted for significant variation in stage structure, no significant difference was found between vegetative and reproductive traits in adult plants, except for the number of flowers. In verge populations the number of flowers was significantly lower as compared to meadow populations. The traits related to reproduction were not significantly influenced by population size. However, the proportion of flowers setting fruit decreased significantly with increasing number of flowers. The stepwise multiple regression revealed significant relationships between soil characteristics and number of fruits per plant, fruit set, number seeds per plant and number of leaves in vegetative adults. The results suggest that the creation of the low and relatively open vegetation cover could increase the chance of persistence of $C$. $a u$ tumnale living in verge habitats by promoting of seed germination, seedling establishment and flowering, and they also show that the reproductive success and vegetative components of fitness are most likely influenced by habitat quality.
\end{abstract}

KEY WORDS: corm geophyte, fitness traits, population size, population viability, plant size, reproductive success, soil characteristics.

\section{INTRODUCTION}

Remnant semi-natural habitats such as verges and ditches often act as a refuge for meadow plant species less tolerant of intensive meadow and pasture management (Blomqvist et al. 2003). These small landscape elements are subjected to higher environmental stochasticity and in long term may not represent a safeguard for local populations (Endels et al. 2002; Jacquemyn et al. 2003). The habitat remnants contain rather small populations of typical species (Schmidt and Jensen 2000) and these populations face an increased risk of extinction (Fischer and Matthies 1998; Leimu and Syrjänen 2002). The relationship between species and their habitats is strong and complicated (Pullin 2002). In recent years known were the adversely affects of habitat fragmentation on structure populations and fitness components, not only rare (Fischer and Matthies 1998;
Lienert et al. 2002; Jacquemyn et. al. 2003), but also common species (Leimu and Syrjänen 2002; Hooftman and Diemer 2002; Lienert and Fischer 2003). The other factors, including local habitat conditions, disturbances and competition with weeds can be just as important as impacts of habitat size and isolation (Hobbs and Yates 2003) and they can affect the population persistence (Endel et al. 2002; Jacquemyn et al. 2003). The stage structure of population can be a much better indicator of its conditions than its age structure (Hutchings 1997; Falińska 2004). The analysis of stage structure can be used as a good tool for quick assessment of viability of plant populations (Oostermeijer et al. 1994; Bühler and Schmid 2001; Hegland et al. 2001). Specific plant traits, such as size and floral display, can influence the fecundity of an individual plant (Brys et al. 2004). Changes in population fecundity may have large implications for seedling recruitment and demographic structure 
of a population (Brys et. al. 2003). Several studies have been conducted on population-stage structure and also on vegetative and reproductive characteristics of forest herbaceous plant species in contrasting habitat types, such as ditch banks, verges of arable field, grasslands and pastures, hedgerows, ancient forests, recently established forests (Jacquemyn et al. 2003; Brys et al. 2004; Endels et al. 2004). So far, the research on demographic structure in populations of meadow plant species concerned mainly the description of viability of populations in relation to environmental features, such as the surrounding vegetation structure, composition, and soil characteristics, management and altitude above sea level (Oostermeijer et al. 1994; Bühler and Schmid 2001; Hegland et al. 2001).

A good understanding of relationships between plant's responses and habitat type and habitat quality is essential for effective conservation and management not only of rare and threatened plant species but also common ones (Hegland et al. 2001; Lienert et al. 2002; Jacquemyn et al. 2003; Vergeer et al. 2003). This information is important if we are to predict the survival of plant species in modern, cultural landscapes (Endels et. al. 2002).

The objective of this paper was to investigate the influence of habitat type and its quality on population persistence of Colchicum autumnale, a meadow specialist in the Sudeten Mts.

The following questions were posed:

1. Are there differences in stage structure, reproductive and vegetative fitness traits of $C$. autumnale in populations occuring in road verges, as compared with populations occuring in meadows?

2. Is reproductive success related to population size and plant size measured as the number of flowers?

3. Is there a relationship between soil conditions and reproductive and vegetative traits?

4. Will road verges in the long term effectively act as habitat refuges for $C$. autumnale?

\section{MATERIAL AND METHODS}

\section{Study species}

Colchicum autumnale (meadow saffron) is an iteroparous perennial geophyte with a corm. It mainly occurs in the southern part of Poland (Zając and Zając 2001). This plant is a characteristic indicator species of moist meadows of the Molinietalia order and a differential species of pastures of the Festuco-Cynosuretum alliance (Matuszkiewicz 2001). In recent decades, a clearly decline in number of localities of this species was recorded (Zarzycki et al. 2002). The species is threatened due to picking flowers in early autumn, digging out entire plants for the private garden use as well as destroying its habitats by drainage and ploughing of meadows (Piękoś-Mirkowa and Mirek 2003). $C$. autumnale suffers also from intensive mowing, grazing and treading as well as nitrogen fertilization and herbicide treatment (Rutkowska 1984). This plant is not threatened with extinction in the Sudeten (Fabiszewski and Kwiatkowski 2002). It occurs mainly in meadows, that are still under traditional management, such as mowing and haymaking or seasonal grazing by domestic cattle and is occasionally found in remnant semi-natural habitats - verges and ditches (Mróz 1996).
Meadow saffron has an unusual life cycle, flower from August to October and fruits in June. Outbreeding with occasional self-fertilization seems to be the predominant breeding system. Flowers are mainly pollinated by flies and bees, sometimes also butterflies (Persson 1993). The interval of time between pollination and fertilization is more than six months (Harper 1977). In spring, higher temperatures induce the emergence of leaves (hysteranthous), followed by the fruits (capsules). Myrmecochory is a general form of seed dispersal. The seeds have an elaisome which is attractive to ants (Persson 1993). Vegetative reproduction of adult individuals can occur. Every year a mother corm produces one or, sometimes, two daughter corms. A corm is in fact constituted by only one internode with two buds (Poutaraud and Girardin 2003). Reserve buds intermittently give rise to new plants via extra corm almost as large as the main corm and remain attached to them. Vegetative offspring spread is restricted and occurs within very short distances from the mother plant (Persson 1999). Plants produced from seeds rarely flower before the 5 year (Persson 1993; Poutaraud and Champay 1995) while plants from daughter corms may flower already next year (personal observations of the autor).

\section{Study area and data collection}

The study area is located in southwestern Poland in Sudeten Mts. The altitude is approximately 350-400 $\mathrm{m}$ above sea level. The slope varies from $2^{\circ}$ to $10^{\circ}$. The soils are loamy-clays with a low skeleton part content. The non-forested parts of the study area are almost all haymeadows and pastures. Arable land is relatively uncommon.

Field studies were carried out in 2000 and 2001 in 15 populations (Table 1). Ten populations occured in meadows extensively mown and grazed, which are referred to simply as meadow populations in the remaining text. Five populations occur in the unmanaged dirt road verges close to shrubs, which are referred to as verge populations. The meadows were composed of primarily Achillea millefolium, Pantago lanceolata, Ranunculus acer, Sanquisorba officinalis, Trifolium pratense, Viccia cracca, Dactylis glomerata, Festuca pratensis, Phleum pratense, Poa pratensis. The verges were composed of primarily Festuca pratensis, Holcus lanatus, Poa pratensis, Plantago lanceolata. The populations are of different effective size (number of flowering plants), area, vegetation type neigbouring, isolation (the distance from one study population to its nearest neighbour population) and barrier (Table 1).

For description of stage structure (sensu Rabotnov 1985; Oostermeijer et al. 1994), i.e., the relative proportions and/or densities of individuals in different ontogenetic stages of the life cycle of populations of $C$. autumnale three different stages were used:

1) seedlings and juveniles with one leaf (i.e. sub-adults),

2) vegetative adults with two or more leaves (non flowering),

3) reproductive adults with flower, having two or more leaves.

At flowering time, in September 2000 in each population were randomly selected and tagged ten $1 \mathrm{~m} \times 1 \mathrm{~m}$ plots for later re-identification. To avoid possible edge effects on stage structure and fitness components, in verge populations plots within a distance of $1 \mathrm{~m}$ from edges of remnant habitats were not chosen. In each plot for an assessment of 
TABLE 1. Number of habitat, coordinates, habitat type, management status, vegetation type neighbouring habitat and barrier type, distance to nearest habitat, population size (number of flowering plants), area extent of population $C$. autumnale for the 15 study sites.

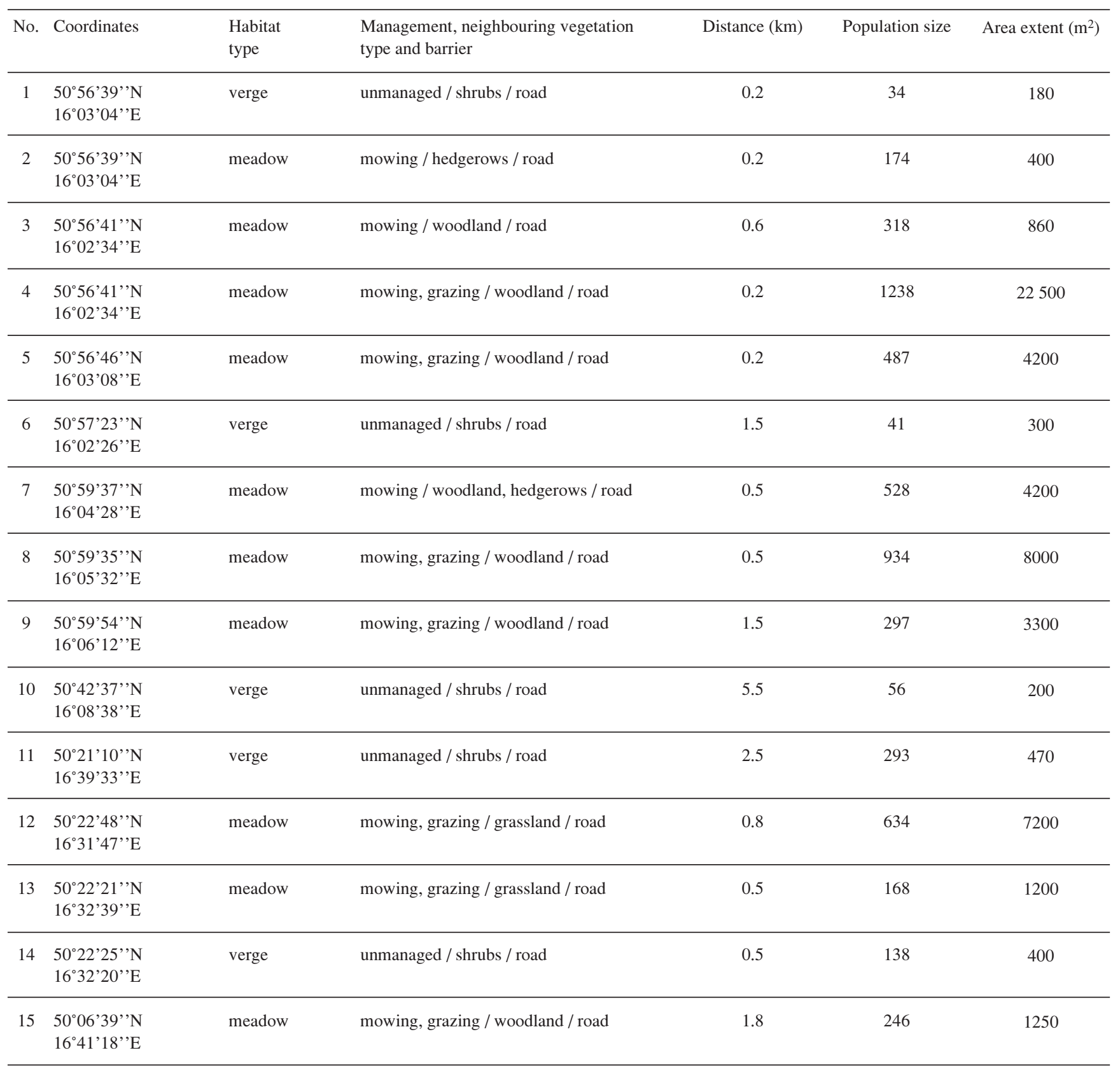

proportions and densities of reproductive adults were counted. Next these reproductive adults were mapped. For these adults, flowering characteristics were determined (Table 2).

At the end of June 2001, all location were visited for the second time and in tagged plots the sub-adults were counted, vegetative adults not attached to the mother plants and the remaining attached to mother plants (i.e., vegetative daughter adults) and fruiting plants. The following rates were calculated: the ratio of vegetative daughter adults to the number of reproductive adults; the ratio of reproductive adults to the total (vegetative + reproductive) number of adults. Afterwards in each plot, one mature, unopened fruit was randomly collected; their seeds were counted and weighed after drying to constant mass at $70^{\circ} \mathrm{C}$. For adults a variety of fitness traits was measured (Table 2). The total flower production increased with increasing number of leaves $(\mathrm{p}<0.05)$. The number of flowers was used as an estimate of plant size. Reproductive success was determined as number of fruits per plant, fruit set, number of seeds per plant, total seed weight per plant (sensu Brys et al. 2004).

For all locations, where stage structure, reproductive and vegetative variables were determined in $C$. autumnale, ten soil samples (30 cm-deep cores) were taken in the neighbourhood of the sampled plants. These samples were airdried, thoroughly mixed and passed through a $2 \mathrm{~mm}$ sieve. The $\mathrm{pH}$ and available nutrients $\mathrm{P}, \mathrm{K}, \mathrm{Mg}, \mathrm{Ca}$ and total $\mathrm{N}$ and $\mathrm{S}$ were determined. The $\mathrm{pH}$ was measured in a 1 $\mathrm{M} \mathrm{KCl}$ solution. The nutrients were extracted using an acetic acid ( $\mathrm{pH}$ 3.1) solution. K, Ca were measured by means of flame photometry and $\mathrm{Mg}$ with use of atomic absorption spectrophotometry, $\mathrm{P}$ by colourimetrically with vanadium molybdate. Soil total N content was determined by the Kjeldahl's method and total S content was determined by 
TABLE 2. Overview of plant traits, measured in $C$. autumnale and total number of reproductive and vegetative adults sampled for each trait. Variable type: $\mathrm{r}$ - reproductive fitness trait, $\mathrm{v}$ - vegetative fitness trait.

Trait

Variable type

Number of plants sampled in

\section{Reproductive adults}

Number of flowers per plant

Length of longest flower $(\mathrm{cm})$

Diameter of longest flower $(\mathrm{cm})$

Number of fruits per plant

Fruit set $=$ number of fruits/number of flowers per plant

Number of seeds per plant $=$ number of seeds per fruits $\times$ number of fruits per plant

Mean individual seed mass $=$ total seed mass from ten fruits/number of seeds $(\mathrm{mg})$

Total seed weight per plant $=$ total number of seeds per plant $\times$ mean seeds mass $(\mathrm{mg})$

Number of leaves $(\mathrm{cm})$

Length of longest leaf $(\mathrm{cm})$

Width of longest leaf $(\mathrm{cm})$

$$
\text { Variable type }
$$

verges meadows

\section{Vegetative adults}

Number of leaves $(\mathrm{cm})$

Length of longest leaf $(\mathrm{cm})$

Width of longest leaf $(\mathrm{cm})$

\begin{tabular}{lll}
$\mathrm{r}$ & 154 & 577 \\
$\mathrm{r}$ & 154 & 577 \\
$\mathrm{r}$ & 154 & 577 \\
$\mathrm{r}$ & 147 & 556 \\
$\mathrm{r}$ & 147 & 556 \\
$\mathrm{r}$ & 147 & 556 \\
$\mathrm{r}$ & 147 & 556 \\
$\mathrm{r}$ & 147 & 556 \\
$\mathrm{v}$ & 154 & 577 \\
$\mathrm{v}$ & 154 & 577 \\
$\mathrm{v}$ & 154 & 577 \\
$\mathrm{r}$ & \\
$\mathrm{v}$ & & \\
$\mathrm{v}$ & 267 & 502 \\
$\mathrm{v}$ & 267 & 502 \\
\hline
\end{tabular}

Carbo Erba NA-1500 CNS Analyzer. The microelements $\mathrm{Fe}, \mathrm{Mn}, \mathrm{Cu}, \mathrm{Zn}, \mathrm{Cd}$ and $\mathrm{Pb}$ were extracted using an $\mathrm{HNO}_{3}$ (conc.) and $\mathrm{HCl}$ (conc.) and measured with AAS (Perkin Elmer ASS 3300). All analyses were done in duplicate.

\section{Data analysis}

The significance of differences between proportions and densities of different stage states, ratios, reproductive and vegetative traits collected in verge and meadow populations were tested with the t-test. Since the size of a population and plant traits can be an important factor influencing the reproductive success of plant populations, simple linear

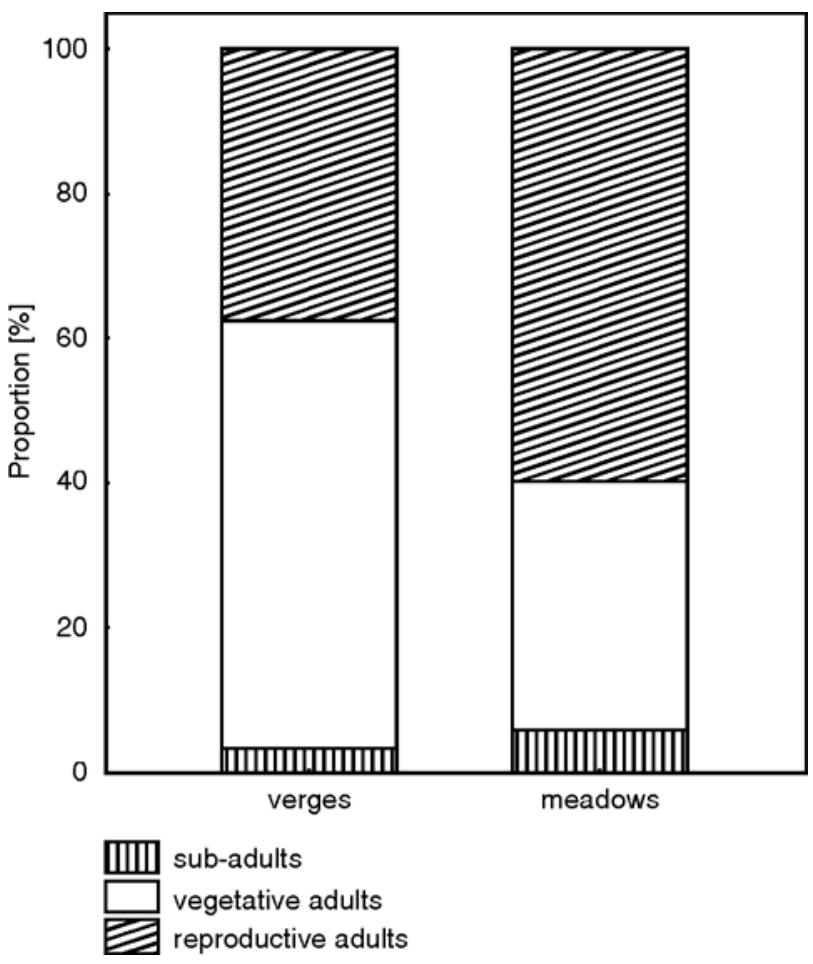

Fig. 1. Effect of habitat type on relative proportions of three developmental stages of $C$. autumnale in 15 populations. Indicated are mean percentages. regression (Pearson's correlation was used) were performed to investigate the possible relationships between population size, plant size (measured as number of flowers) and fruit set, number of fruits per plant, number of seeds per plant, total seed weight per plant. Since soil variables were partly interdependent, the PCA (principal component analysis VARIMAX normalized) was used to reduce the set of variables to uncorrelated components. To investigate whether there were relationships between chemical composition of soil and vegetative and reproductive traits, sample scores for rotated principal components were used as soil variables for further multiple, stepwise regression analysis (with forward stepwise procedure). Forward steps include the most significant term into the model that satisfies the probability to enter. The fitness traits of reproductive and vegetative adults were used as dependent variables. Soil variables were used as independent variables. If the raw data were not normally distributed, the data were transformed to meet the assumptions for parametric tests. Angular transformation (arcsin) for proportions, square root transformation for densities and logarithmic transformation for ratios and reproductive and vegetative traits was applied (Zar 1999; Łomnicki 2003). All analyses were performed with Statisica 6.0 program (StatSoft Inc. 2003).

\section{RESULTS}

\section{Stage structure, fitness components and habitat type}

The proportion of plants of all stages differed significantly between the two studied habitats. In verge populations the proportions of sub-adults and reproductive adults were significantly lower, and of vegetative adults significantly higher as compared with meadow populations (Table 3, Fig. 1). No significant differences in density of sub-adults and vegetative adults between verge and meadow populations were found. However, plant density of reproductive adults was significantly lower in verge populations as compared with meadow populations (Table 3, Fig. 2). In verge populations, the ratio of vegetative daughter adults to the 
TABLE 3. Results of t-test of mean estimates of proportions, densities of three developmental states, ratios and fitness traits of. $C$. autumnale. t-statistic and significance $($ at $\mathrm{p}<0.05)$ are shown for each test.

\begin{tabular}{lcc}
\hline Variable & $\mathrm{t}$ & $\mathrm{p}$ \\
\hline Proportion & & \\
Sub-adults & -2.19 & 0.047 \\
Vegetative adults & 3.59 & 0.003 \\
Reproductive adults & -2.99 & 0.01 \\
\hline Density & & \\
Sub-adults & -2.02 & 0.063 \\
Vegetative adults & -0.29 & 0.77 \\
Reproductive adults & -3.31 & 0.006 \\
\hline Ratio & & \\
Vegetative daughter adults/ reproductive adults & 4.40 & 0.0007 \\
Reproductive adults/all adults & -3.45 & 0.004 \\
\hline Reproductive fitness traits & & \\
Number of flowers/plant & & \\
Length of longest flower & -6.13 & 0.00004 \\
Diameter of longest flower & 0.82 & 0.43 \\
Number of fruits/plant & -0.13 & 0.90 \\
Fruit set & -0.54 & 0.60 \\
Number of seeds/plant & 1.97 & 0.07 \\
Total seed weight/plant & -1.23 & 0.24 \\
\hline Vegetative fitness taits & -0.44 & 0.67 \\
\hline
\end{tabular}

Vegetative fitness traits

Reproductive adults
Number of leaves

Length of longest leaf

Width of longest leaf

Vegetative adults

Number of leaves

Length of longest leaf

Width of longest leaf

$\begin{array}{cc}0.63 & 0.54 \\ 0.36 & 0.72 \\ -1.84 & 0.09\end{array}$

0.09 $\mathrm{n}=15)$ and total seed weight per plant $(\mathrm{r}=-0.20, \mathrm{p}=0.46$, $\mathrm{n}=15)$.

\section{Reproductive and vegetative traits and status of soil}

The number of fruits per plant, fruit set, number of seeds per plant and number of leaves per vegetative adult, are mainly determined by soil characteristics (Table 4 and 5).

The standardized partial regression coefficient $(\beta)$ indicated that the response was significant positively $(\mathrm{p}<0.05)$ related to PC 1 (principal component axis 1, increasing $\mathrm{pH}, \mathrm{Ca}$ and $\mathrm{Mg}$ ) for number of fruits per plant, fruit set and number of seeds per plant, and to PC 2 (principal component axis 2 , increasing $\mathrm{N}$ and $\mathrm{K}$ and decreasing $\mathrm{Cu}$ ) for number of leaves per vegetative adult. The relationship was significantly negative between PC 2 and number of fruits per plant and number of seeds per plant, and between PC 3 (principal component axis 3, decreasing $\mathrm{Fe}$ and $\mathrm{Mn}$ and increasing $\mathrm{Cd}$ ) and number of leaves per vegetative adult.

\section{DISCUSSION}

In the present study a significant reduction of proportions of sub-adults and reproductive adults was observed, as well as the increase of vegetative adults in verge populations as compared with meadow populations (Table 3, Fig. 1). Reduced seedling performance, and increased number of vegeteative adults in populations were found in the two common fen spiecies Carex davalliana in response to isolation, and Succisa pratensis in response to small habitat size (Hooftman et al. 2003). The lower sub-adults performance in habitat shows that the conditions must be suboptimal for seedlings recruitment and growth of juveniles (Endels et al. 2004). The seeds of Colchicum autumnale are generally ripe at the end of June. Germination occurs mainly in autumn. The seed germination rate is very low, based on laboratory germination tests (Poutaraud and Champay 1995). The seedling recruitment in populations is conditioned by the safe-sites for germination and by the growth form of neighbours (Isselstein et al. 2002; Falińska 2004). The studied meadows are annually mown for hay, at the end of June or at the beginning of July, whereas the verges are not. Due to the lack of appropriate management, seed germination and seedling survival can probably hamper the necromass accumulation and the vegetation layer as a result of the canopy-shrubs shade. Abandonment of mowing, may be the first step in population decline, causing a reduced germination or seedling recruitment. It is very likely that this process will not actually cause the population extinction, but it will obviously affect the population size and composition (Endels et al. 2002). Density of reproductive adults was significantly decreased in verge populations (Table 3, Fig. 2). Such significant lowered densities of reproductive adults were observed in rare species Swertia perennis in isolated, small fens, that may be a result of arrested individual adult growth (Lienert et al. 2002). Moreover, these studies revealed the significantly lower reproductive adults to all adults ratio in verge populations (Table 3, Fig. 3). In response to deterioration of habitat conditions, plant populations may not reproduce (Falińska and Gliwicz 1986). Thus it seems that the conditions of verges are not favourable for this species and this may negatively plant was independent of plant size $(r=-0.04, p=0.88$, $\mathrm{n}=15)$, and of number of seeds per plant $(\mathrm{r}=0.046, \mathrm{p}=0.87$, 

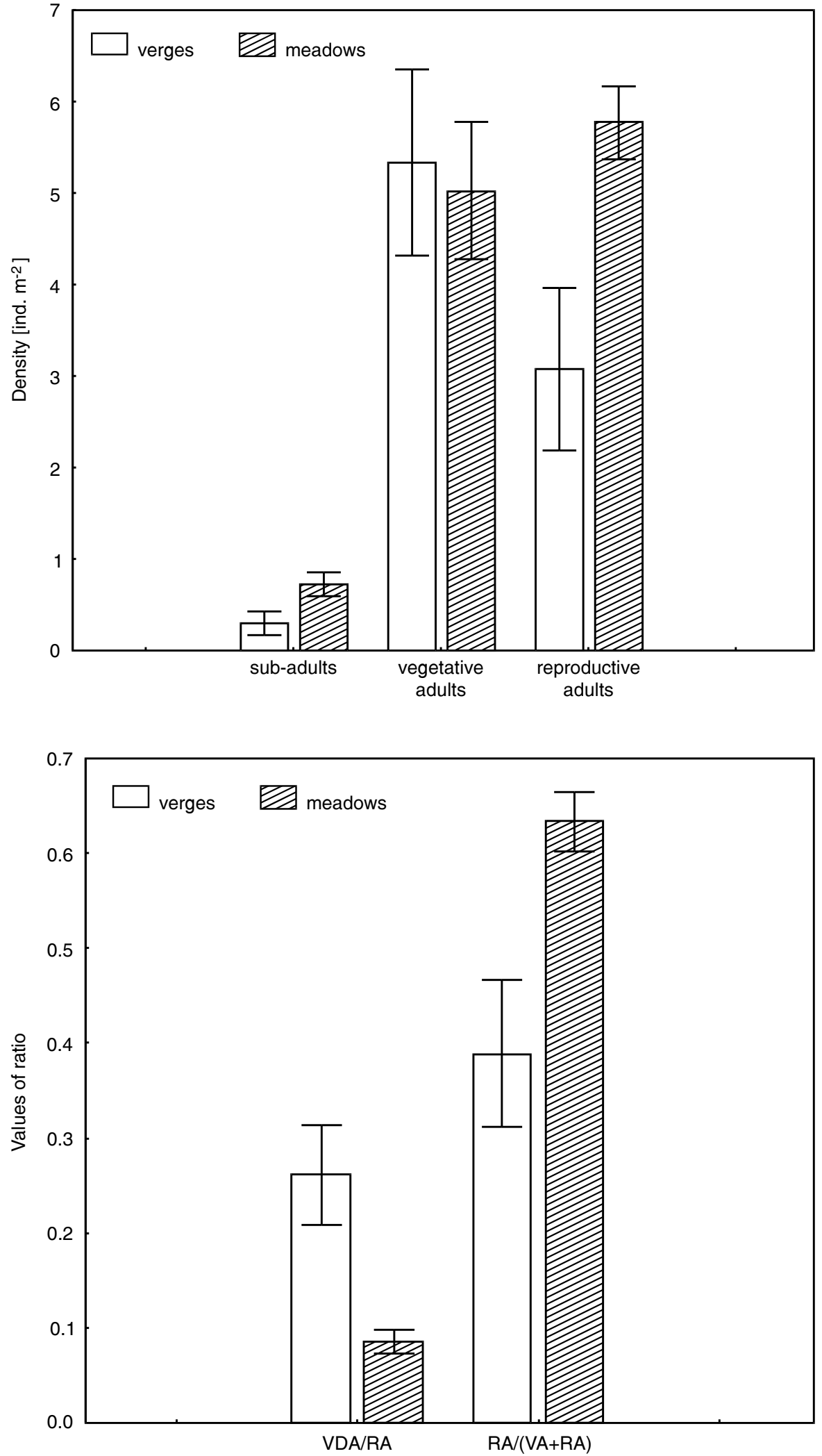

Fig. 2. Effect of habitat type on densities of three developmental stages of $C$. autumnale in 15 populations. Indicated are means and standard errors of means.
Fig. 3. Effect of habitat type on the VDA/RA ratio - of vegetative daugether adults to the number of reproductive adults and the $\mathrm{RA} /(\mathrm{VA}+\mathrm{RA})$ ratio - of reproductive adults to the total (vegetative + reproductive) number of adults of $C$. autumnale in 15 populations. Indicated are means and standard errors of means. affect the population viability in the future. However a significantly higher ratio of vegetative daughter adults to the number of reproductive adults in verge populations as compared with meadows, was observed (Table 3, Fig. 3). Godet (1987) noticed that, depending on the site, from $0 \%$ to $30 \%$ of the reserve buds of mother corms develop simultaneously in September to give two new plants in June. Poutaraud and Girardin (2003) pointed out, that in the cultivated crop, $47 \%$ of the fruiting plants produced two new plants (corms) every year. In verge populations $26 \%$ of single mother corms produce two daughter corms as compared with $9 \%$ in meadow populations. This indicates that meadow saffron may have compensated for the negative effects of remnant habitats via increased clonal growth. The vegetative reproduction in clonal species plants enables the spatial and temporal dispersal and ensures longterm existence in their habitat (Falińska 2004). Though the number of individuals of $C$. autumnale is augmented in this 


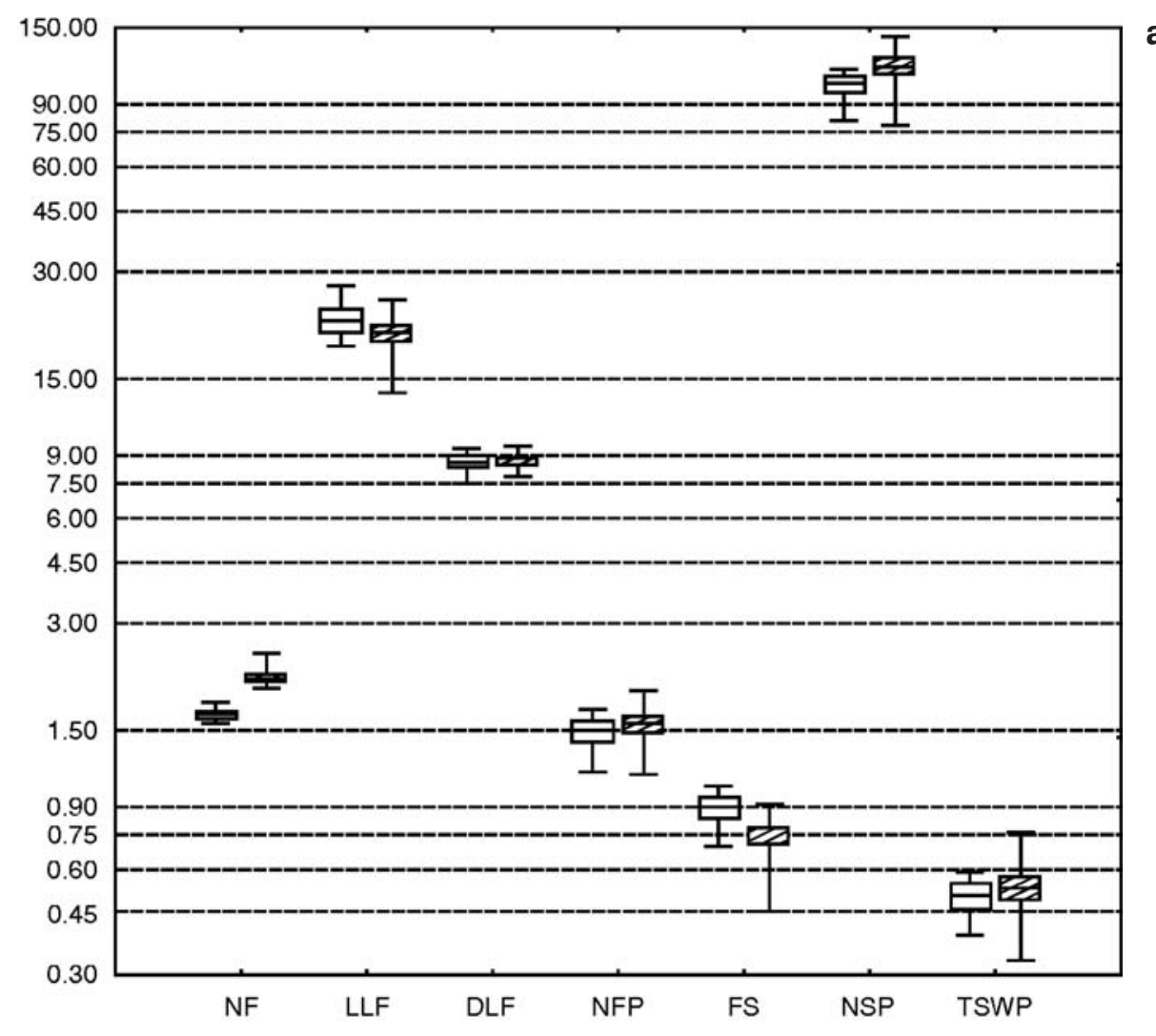

meadows

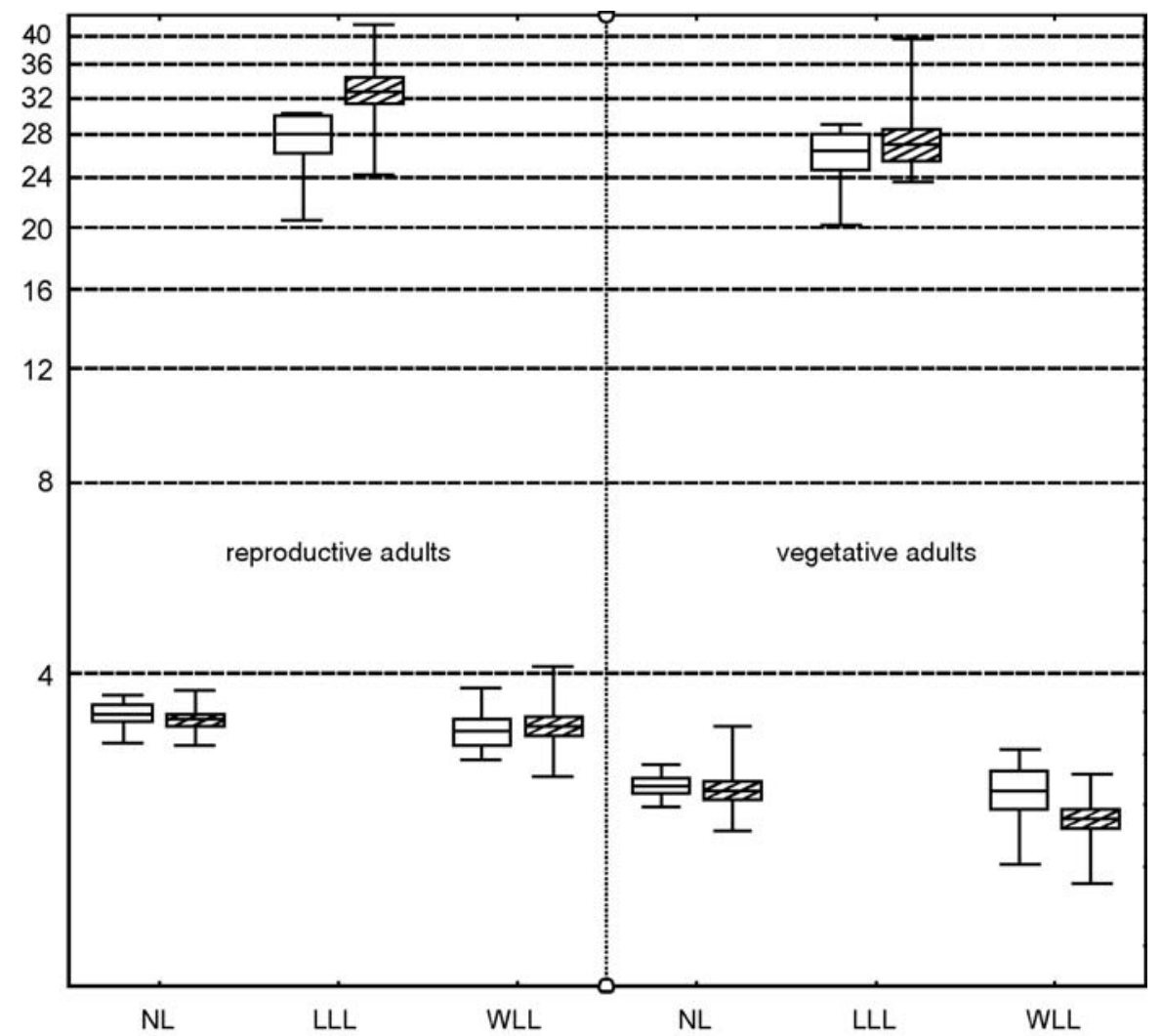

Fig. 4. Effect of habitat type on (a) reproductive and (b) vegetative components of $C$. autumnale in 15 populations: $\mathrm{NF}$ - number of flowers; LLF - length of longest flower; DLF - diameter of longest flower; NFP number fruits per plant; FS - fruit set; NSP number of seeds per plant; TSWP - total seed weight per plant; NL - number of leaves; LLL - length of longest leaf; WLL - width of longest leaf. Indicated are mean values and minimum and maximum (note log-scale 


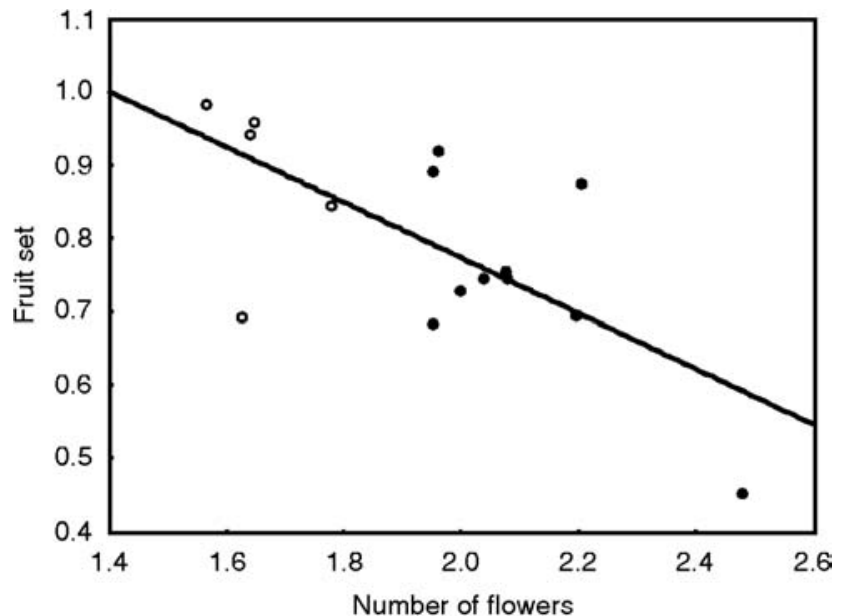

Fig. 5. Relationship between number of flowers and proportion of flower setting fruit of $C$. autumnale in 15 populations. Open circles - verge populations; filled circles - meadow populations.

way, but the area of each clone and of the population will grow rather slowly (Persson 1993).

The habitat type gave account of the significant variation in stage structure however, no significant difference was found between the vegetative and reproductive traits in adult plants, except for the number of flowers (Table 3, Fig. 4). Plants of $C$. autumnale in verge populations produced less flowers than plants in meadow populations. A reduced number of flowers in small populations was found in the grassland species Gentiana cruciata (Kery et. al. 2001) and the forest herb Primula elatior (Jacquemyn et. al. 2002) and the wetland specialist Primula farinosa (Lienert and Fischer 2003) and it were attributed to reduction of individual fitness of plants. $C$. autumnale is a short-day plant, light demanding (sun species) but it also is periodic shade-tolerant (Piękoś-Mirkowa and Mirek 2003). The lower light availability, especially during the short day, delays flowering and reduces the potential reproduction, so it causes that some plant species do not flower after reaching maturity, or develop only single flowers (Falińska and Gli-
TABLE 4. Principal components analysis (PCA) factor loadings for 13 soil variables determined in the soil samples from 15 populations after varimax rotation. Only principal components with eigenvalues greater than 1 are presented. Factor loadings in italics indicate variables significantly correlated with given principal component. Together, the three axes explained $70.4 \%$ of the total variance.

\begin{tabular}{lccc}
\hline \multirow{2}{*}{ Soil variable } & \multicolumn{3}{c}{ Principal component axis } \\
\cline { 2 - 4 } & 1 & 2 & 3 \\
\hline $\mathrm{pH}$ & $\mathbf{0 . 8 3}$ & 0.23 & 0.13 \\
$\mathrm{~N}$ & -0.37 & $\mathbf{0 . 7 8}$ & -0.14 \\
$\mathrm{P}$ & 0.63 & 0.51 & -0.05 \\
$\mathrm{~K}$ & -0.30 & $\mathbf{0 . 8 0}$ & 0.41 \\
$\mathrm{Ca}$ & $\mathbf{0 . 8 8}$ & 0.03 & 0.25 \\
$\mathrm{Mg}$ & $\mathbf{0 . 8 9}$ & -0.25 & 0.20 \\
$\mathrm{~S}$ & 0.35 & 0.54 & 0.34 \\
$\mathrm{Fe}$ & 0.01 & $-0,1$ & $-\mathbf{0 . 8 2}$ \\
$\mathrm{Mn}$ & -0.08 & 0.1 & $\mathbf{- 0 . 8 9}$ \\
$\mathrm{Cu}$ & -0.28 & $-\mathbf{0 . 7 9}$ & -0.10 \\
$\mathrm{Zn}$ & 0.64 & 0.06 & -0.09 \\
$\mathrm{~Pb}$ & 0.13 & 0.56 & -0.04 \\
$\mathrm{Cd}$ & 0.55 & -0.14 & $\mathbf{0 . 7 2}$ \\
Eigenvalue & 3.83 & 2.90 & 2.43 \\
Variance explained & 34.19 & 22.14 & 14.10 \\
(\% of total) & & & \\
\hline
\end{tabular}

wicz 1986). The nearest neighbour plants (mainly grasses and shrubs) have probably reduced the quality of the habitat by competition and increasing shading consequently affecting the flowers display in verge populations. Godet (1987) remarked, that the decrease in competition with plants on a natural site induced the increase in number of flowers of $C$. autumnale.

In this investigation, the proportion of flowers setting fruit decreased significantly with increasing number of flowers (Fig. 5). Willson (1991) and Leimu and Syrjänen (2002) pointed out, that in milkweeds and in Vincetoxicum hirundinaria (Asclepiadaceae) the individuals with a higher number of flowers attract more pollinators and have higher male reproductive success an increased pollen donation, but lower rates of fruit production (less than $10 \%$ in $\mathrm{V}$. hirudinaria). In C. autumnale $45 \%$ to $98 \%$ of flowers produ-

TABLE 5. Multiple stepwise regression analyses (forward selection) of habitat quality (three PC axes) on vegetative and reproductive fitness components of $C$. autumnale. Only the significant models and the significant predictor variables, after forward selection are shown.

$\beta$ - standardized partial regression coefficient; $\mathrm{t}$ - $\mathrm{t}$-statistic; $\mathrm{p}$ - probability level; $\mathrm{df}$ - degrees of freedom; MS - mean square; $\mathrm{F}$ - F-statistic; $\mathrm{R}^{2}$ - square multiple regression coefficient.

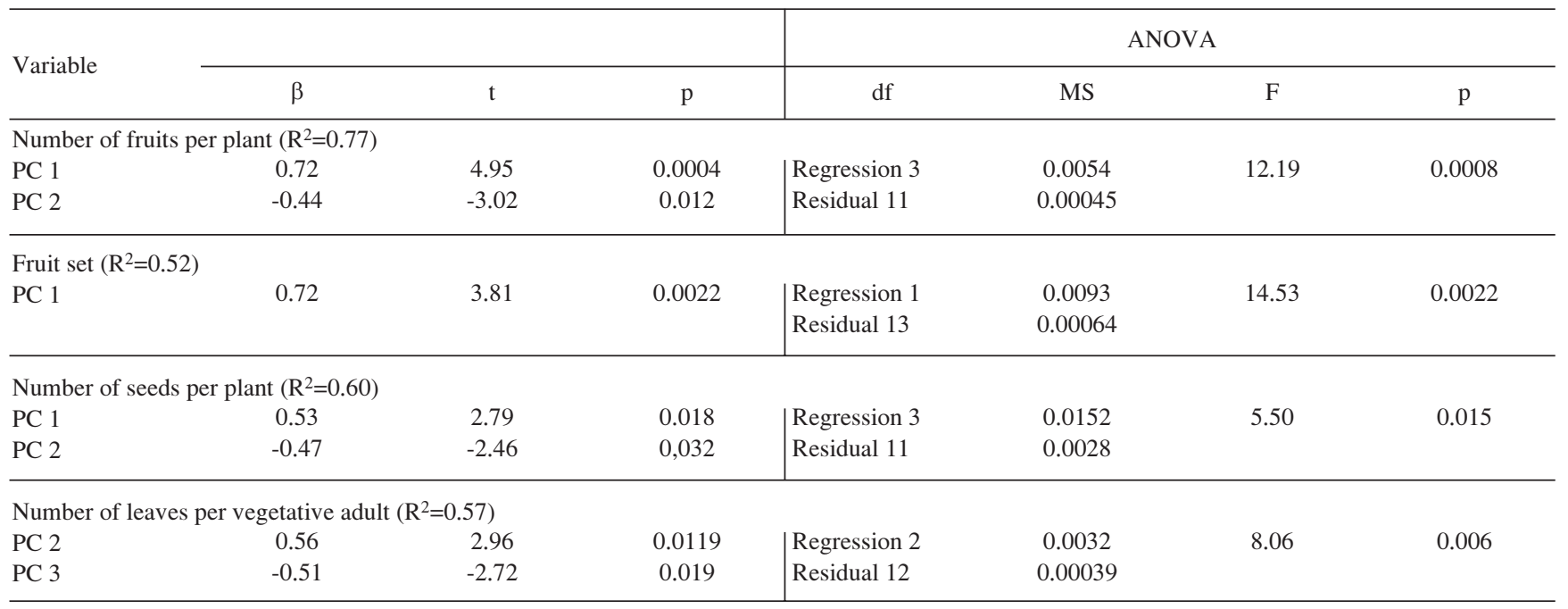


ced fruits (capsules). The costs of fruit production and the pollination efficiency interact (Lee 1988). Fruit (capsules) produced by meadow saffron are big, ca. 3-6 6 1.5-2.6 cm (Persson 1999). In plants with big fruits the resources of maternal plant may limit the number of produced fruits (Lee 1988). Another possible explanation for the reduced fruit set in individuals with a higher number of flowers is, that biotic interaction between plants and pollinators may have become disrupted. In autumn relatively few insects, mainly flies and bees are active. An increase in pollination success during a harsh season for insects may be realized by large flowers, long exposure of flowers and self-pollination. All these adaptations can be found in $C$. autumnale (Dafni 1996). However, Godet (1987) and Poutaraud and Girardin (2003) stated that the number of fruiting plants of meadow saffron can fluctuate depending on the year, probably due to the lack of pollination.

Several authors (Schmidt and Jensen 2000; Jacquemyn et al. 2002, 2003) indicate, that soil characteristics may influence the variation of reproductive components. In this study it was shown that several components related to reproduction, i.e. the number of fruits per plant, fruit set and number of seeds per plant and one vegetative component, i.e. the number of leaves of vegetative adults was significantly related to soil parameters. The soil $\mathrm{pH}, \mathrm{Ca}, \mathrm{Mg}$ concentration and $\mathrm{N}, \mathrm{K}$ and $\mathrm{Cu}$ content appeared to be the main factors determining the reproductive success of this species (response was positive and negative respectively); soil $\mathrm{N}, \mathrm{K}$ and $\mathrm{Cu}$ concentration and $\mathrm{Fe}, \mathrm{Mn}$ and $\mathrm{Cd}$ content appeared to be the main factors determining the growth of the vegetative plant parts in vegetative adults (response was positive and negative respectively; Table 4 and 5). This is in agreement with data of Lityński and Jurkowska (1982), who reported that fruit and seed production as well as the growth of vegetative parts of plants are closely associated with the soil macro-, and micronutrient level (primarily $\mathrm{N}$, $\mathrm{K}, \mathrm{Ca}, \mathrm{Mg}, \mathrm{Fe}, \mathrm{Mn}, \mathrm{Cu}$ ) with the exception of $\mathrm{Cd}$. Cadmium is a heavy metal which can be strongly phytotoxic. It seems that soil $\mathrm{Cd}$ concentration can be detrimental to the growth of young plant species and can significantly modify the growth parameters (Kabata-Pendias and Pendias 2001).

Many studies have found a positive relation between population size and reproductive success of plants (Fischer and Matthies 1998; Schmidt and Jensen 2000; Jacquemyn et. al. 2002, 2003; Brys et. al. 2004), although no clear association was also observed (Mustajärvi et al. 2001; Leimu and Syrjänen 2002). In this study, the traits related to reproduction were not significantly influenced by population size. It appears that the reproductive success of $C$. autumnale is in small populations not necessarily lower as compared to larger populations.

The results of this study suggest that competition (light availability) and management practice, contribute to the variation in population-stage structure and display flower of $C$. autumnale. The reproductive success may be influenced by plant size measured as number of flowers and soil characteristics. The status of soil can also influence the variation of vegetative fitness components, i.e. number of leaves of vegetative adults.

It seems that seed germination, survival of sub-adults and promotion of flowering plants is possible in verge populations, if the conditions are created by the low and relatively open vegetation cover. In general, meadows have a higher probability of occupation than verges, so it indicates that the verges may be less able to support sustainable populations of meadow plant species. In verge populations the sub-adults were present, but most of the plants were adult individuals. Populations, in which recruitment occasionally took place, but the adults still made up the largest part of the population, were classified as stable (normal) populations (Jacquemyn et. al. 2003; Brys et al. 2003). Thus, the road verges in the study area, seem to be occupied by stable populations of $C$. autumnale. The obtained study results confirm the findings of Endels et al. (2004), that small landscape elements, in areas, which were never very intensively cultivated may contain viable (i.e. stable or growing) populations of corm geophytes.

\section{LITERATURE CITED}

BLOMQVIST M.M., VOS P., KLINKHAMER P.G.L., TER KEURS W.J. 2003. Declining plant species richness of grassland ditch banks - a problem of colonisation or extinction? Biol. Conserv. 109: 391-406.

BRYS R., JACQUEMYN H., ENDELS P., HERMY M., DE BLUST G. 2003. The relationship between reproductive success and demographic structure in remnant populations of Primula veris. Acta Oecol. 24: 247-253.

BRYS R., JACQUEMYN H., ENDELS P., VAN ROSSUM F., HERMY M., TRIEST L., DE BRUYN L., BLUST G.D.E. 2004. Reduced reproductive success in small populations of the self-incompatible Primula vulgaris. J. Ecol. 92: 5-14.

BÜHLER CH., SCHMID B. 2001.The influence of management regime and altitude on the population structure of Succisa pratensis: implication for vegetation monitoring. J. Appl. Ecol. 38: 689-698.

DAFNI A. 1996. Autumnal and winter pollination adaptations under Mediterranean conditions. Bocconea 5: 171-181.

ENDELS P., JACQUEMYN H., BRYS R., HERMY M., DE BLUST G. 2002. Temporal changes (1986-1999) in populations of primrose (Primula vulgaris Huds.) in an agricultural landscape and implications for conservation. Biol. Conserv. 105: 11-25.

ENDELS P., ADRIAENS D., VERHEYEN K., HERMY M. 2004. Population structure and adult plant performance of forest herbs in three contrasting habitats. Ecography 27: 225-241.

FABISZEWSKI J., KWIATKOWSKI P. 2002. Threatended vascular plants of the Sudeten Mountains. Acta Soc. Bot. Pol. 71, 4: 339-350.

FALIŃSKA K. 2004. Ekologia roślin. PWN, Warszawa, 512 pp. (in Polish)

FALIŃSKA K., GLIWICZ J. 1986. Rozrodczość. In: Populacje roślin i zwierząt, ekologiczne studium porównawcze. Adrzejewski R. and Falińska K. (eds). PWN, Warszawa, pp. 225-256. (in Polish)

FISCHER M., MATTHIES D. 1998. Effects of population size on performance in the rare plant Gentianella germanica. J. Ecol. 86: 195-204.

GODET X. 1987. Biologie du colchique (Colchicum autumnale L.). Multiplication végétative par voie traditonelle et in vitro. Thčse, Clermont-Ferrand, $172 \mathrm{pp}$.

HARPER J.L. 1977. Population biology of plants. Academic Press, London-New York-San Francisco, 892 pp.

HEGLAND S.J., VAN LEEUWEN M., OOSTERMEIJER J.G.B. 2001. Population structure of Salvia pratensis in relation to vegetation and management of Dutch dry floodplain grassland. J. Appl. Ecol. 38: 1277-1289.

HOBBS R.J., YATES C.J. 2003. Impacts of ecosystem fragmentation on plant populations: generalizing the idiosyncratic. Aust. J. Bot. 51: 471-488. 
HOOFTMAN D.A.P., DIEMER M. 2002. Effects of small habitat size and isolation on the population structure of common wetland species. Plant Biology 4: 720-728.

HOOFTMAN D.A.P., VAN KLEUNEN M., DIEMER M. 2003. Effects of habitat fragmentation on the fitness of two co wetland species Carex davalliana and Succisa pratensis. Oecologia 134: 350-359.

HUTCHINGS M.J. 1997. The structure of plant populations. In: Plant Ecology. Crawley M.J. (ed.), Blackwell Science, Oxford, pp. 325-358.

ISSELSTEIN J., TALLOWIN J.R.B., SMITH R.E.N. 2002. Factors affecting seed germination and seedling establishment of fen-meadow species. Restor. Ecol. 10,2: 173-184.

JACQUEMYN H., BRYS R., HERMY M. 2002. Patch occupancy, population size and reproductive success of a forest herb (Primula elatior) in a fragmented landscape. Oecologia 130: 617-625.

JACQUEMYN H., VAN ROSSUM F., BRYS R., ENDELS P., HERMY M., TRIEST L., DE BLUST G. 2003. Effects of agricultural land use and fragmentation on genetics, demography and population persistance of the rare Primula vulgaris, and implication for conservation. Belg. Journ. Bot. 136, 1: 5-22.

KABATA-PENDIAS A., PENDIAS H. 2001.Trace elements in soils and plants. CRC Press, Boca Raton, 413 pp.

KERY M., MATTHIES B., FISCHER M. 2001. The effect of plant population size on the interactions between the rare plant Gentiana cruciata and its specialized herbivore Maculinea rebeli. J. Ecol. 89: 418-427.

LEE T.D. 1988. Patterns of fruit and seed production. In: Plant reproductive ecology: Patterns and strategies. Lovett Doust J. and Lovett Doust L. (eds). Oxford University Press USA, New York, pp. 179-201.

LEIMU R., SYRJÄNEN K. 2002. Effects of population size, seed predation and plant size on male and female reproductive success in Vincetoxicum hirundinaria (Asclepiadaceae). Oikos 98: 229-238.

LIENERT J., DIEMER M., SCHMID B. 2002. Effects of habitat fragmentation on population structure and fitness components of the wetland specialist Swertia perennis (Gentianaceae). Basic Appl. Ecol. 3: 101-114.

LIENERT J., FISCHER M. 2003. Habitat fragmentation affects the common wetland specialist Primula farinosa in north-east Switzerland. J. Ecol. 91: 587-599.

LITYŃSKI T., JURKOWSKA H. 1982. Żyzność gleby i odżywianie się roślin. PWN, Warszawa, 643 pp. (in Polish)

ŁOMNICKI A. 2003. Wprowadzenie do statystyki dla przyrodników. PWN, Warszawa, 263 pp. (in Polish)

MATUSZKIEWICZ W. 2001. Przewodnik do oznaczania zbiorowisk roślinnych Polski. PWN, Warszawa, 536 pp. (in Polish)

MRÓZ L. 1996. Ekologiczna charakterystyka populacji Colchicum autumnale L. i warunków ich występowania w Nowych Rochowicach koło Bolkowa. Acta Univ. Wrat. 1835, Prace Bot. 68: 53-68. (in Polish with English summary)
MUSTAJÄRVI K., SIIKAMÄKI P., RYTKÖNEN S., LAMMI A. 2001. Consequences of plant population size and density for plant-pollinator interactions and plant performance. J. Ecol. 89: 80-87.

OOSTERMEIJER J.G.B., VAN'T VEER R., DEN NIJS J.C.M. 1994. Population structure of the rare long-lived perennial Gentiana pneumonanthe in relation to vegetation and management in the Netherlands. J. Appl. Ecol. 31: 428-438.

PERSSON K. 1993. Reproductive strategies and evolution in Colchicum - Proceed. $5^{\text {th }}$ OPTIMA Meeting, Istanbul, 8-15 September 1986, pp. 397-414.

PERSSON K. 1999. New and revised species of Colchicum (Colchicaceae) from the Balkan Penisula. Pl. Syst. Evol. 217: 55-80.

PIĘKOŚ-MIRKOWA H., MIREK Z. 2003. Atlas roślin chronionych. Flora Polski. Multico, Warszawa, pp. 198-199. (in Polish)

POUTARAUD A., GIRARDIN P. 2003. Seed yield and components of alkaloid of meadow saffron (Colchicum autumnale) in natural grassland under cultivation. Can. J. Plant Sci. 83, 1: 23-29.

PULLIN A.S. 2002. Conservation Biology. Cambridge University Press, 358 pp.

RABOTNOV T.A. 1985. Dynamics of plant coenotic populations. In: The population structure of vegetation. White J. (ed.). W. Junk Publishers, Dordrecht, pp. 121-142.

RUTKOWSKA B. 1984. Atlas roślin łąkowych i pastwiskowych. PWRiL, Warszawa, 367 pp. (in Polish)

SCHMIDT K., JANSEN K. 2000. Genetic structure and AFLP variation of remnant populations in the rare plant Pedicularis palustris (Scrophulariaceae) and its relation to population size and reproductive components. Am. J. Bot. 87, 5: 678-689.

STATSOFT Inc. 2003. Statistica (data analysis softwere system), version 6. StatSoft Inc., Tulsa, USA.

TUTIN T.G., HEYWOOD V.H., BURGESS N.A., MORE D.M., VALENTINE D.H., WALTERS S.M., WEBB D.A. 1980. Flora Europea. Alismataceae to Orchidaceae (Monocotyledones). Cambridge University Press, Cambridge pp. 21-25.

WILLSON M.F. 1991. Sexual selection, sexual dimorphism and plant phylogeny. Evol. Ecol. 5: 69-87.

VERGEER P., RENGELINK R., OUBORG N.J., ROELOFS J.G.M. 2003. Effects of population size and genetic variation on the response of Succisa pratensis to eutrophication acidification. J. Ecol. 91: 600-609.

ZAJĄC A., ZAJĄC M. 2001. Distribution atlas of vascular plants in Poland. Laboratory of Computer Chorology, Institute of Botany, Jagiellonian University, Cracow, pp. 171. (in Polish with English summary)

ZAR J.H. 1999. Biostatistical analysis. Prentice Hall, Upper Saddle River, New Jersey, 663 pp.

ZARZYCKI K., TRZCIŃSKA-TACIK H., RÓŻAŃSKI W., SZELĄG Z., WOŁEK J., KORZENIAK U. 2002. Ecological indicator values of vascular plants of Poland. Biodiversity of Poland 2. W. Szafer Institute of Botany, Polish Academy of Sciences, Cracow, 183 pp. (in Polish with English summary) 